\title{
The cognitive dissonance between the rule of law and rural realities: Reading Gillian Hadfield's Rules for a Flat World in the context of rural identity and politics
}

Danielle M. Conway

University of Maine School of Law, dconway@maine.edu

Follow this and additional works at: https://digitalcommons.mainelaw.maine.edu/facultypublications

Part of the Rule of Law Commons

\section{Suggested Bluebook Citation}

Danielle M. Conway, The cognitive dissonance between the rule of law and rural realities: Reading Gillian Hadfield's Rules for a Flat World in the context of rural identity and politics, 5 Creighton J. Interdisc. Leadership 4 (2019).

Available at: https://digitalcommons.mainelaw.maine.edu/faculty-publications/109 


\title{
The cognitive dissonance between the rule of law and rural realities: Reading Gillian Hadfield's Rules for a Flat World in the context of rural identity and politics
}

\author{
Danielle M. Conway. B.S., J.D., LL.M. \\ Outgoing Dean and Professor of Law, University of Maine School of Law, Incoming Dean \\ and Donald J. Farage Professor of Law, Penn State University's Dickinson School of \\ Law,dconway@maine.edu
}

\begin{abstract}
Rural communities - as well as other marginalized communities - see their access to legal infrastructure declining, so much so that they feel disconnected from the rule of law. Current complex law and legal infrastructure focus on big "I" innovation, which is hyper-transactional and benefits the few. Rural communities, and others, would find law and legal infrastructure more relevant if they focused more on small "i" innovation, which centers on negotiating real, societal relationships.
\end{abstract}

Keywords: rule of law, rural communities, hyper-transactionality, relationality

Video Interview with Danielle Conway (2:51): "When all communities are engaged with the rule of law, it makes the rule of law stronger." https://youtu.be/JV6P3Wv17DI

$\mathrm{T}$

he invitation to serve as a discussant of Gillian Hadfield's Rules for a Flat World, provided a space to disconnect from the frenetic daily onslaught of tasks - from the parochial to the seemingly insurmountable - associated with leading a law school during a time of chronic crises in the legal academy and the legal profession. To be sure, the crises facing the legal academy, on the one hand, and the legal profession, on the other-with particular emphasis on the BigLaw segment of the profession - are anything but consonant: The two, in my opinion, generally have not been aligned for some time. This observation provides the first hint of dissonance that partly frames these remarks.

I am grateful for this forum and for this opportunity because first and foremost I got the chance to actually read a book. As an administrator, this has been a real luxury. Second, I appreciate the opportunity to think much more deeply about the layers of dissonance experienced among members of the legal profession, but more so and, more importantly, by segments of American communities that are told about the virtues of the rule of law, yet are excluded from its benefits. Worse, these communities are intentionally being divested of the right to participate in what is the singular value proposition of the American constitutional democracy: the rule of law.

I frame my discussion by addressing specifically how rural communities-inclusive of First Peoples, white Americans, people of color, and immigrants - see their access to legal infrastructure declining, so much so that they feel disconnected from the rule of law. This second layer of dissonance leads those living rural realities to become further disenfranchised by the absence of the rule of law and the corresponding absence of legal infrastructures that do not recognize rural identities.

My observation is that our American economy and the legal infrastructure that supports it do not focus on rural realities, identities, and politics. From our markets to our graduate and professional schools and our global networks to our innovators and philanthropists, we find little or no value in focusing on small ' $i$ ' innovation, which should include the integration of 
these segments of our communities. Instead, we pursue big "I" innovation design plans, which reflect mainstream society's narrow definition of progress. This narrow conception of progress can be examined through various lenses, such as the powerful-vulnerable divide, urban-rural divide, the digital-analog divide, the wealth-poverty divide, the privileged-disadvantaged divide, the gender divide, the racial divide, and so on. When wrestling with notions of whether the rule of law and its legal infrastructure have become too complex to manage our transactions and relationships, I query whether this complexity was intended to privilege certain segments of our community over others. For this discussion, I focus on the urban-rural divide knowing that it intersects with other lenses.

Rural communities have only recently emerged onto the national stage as a topic of mainstream discussion, largely because of the new political landscape. Rural spaces and population remain largely unfamiliar to much of our nation's population, which is $84 \%$ urban. Yet, more than $75 \%$ of the land mass of the United States is rural, and rural populations are driving important political, social, and legal conversations. A forum for discussing rural life, law, and policy and bringing balanced civil discourse to the fore should be considered small "i" innovation. The legal infrastructure and those who move the levers in it-including lawyer leaders, business leaders, and public policy leader - can collaborate to bring light to the current circumstances that shape rural existence and the motivations that influence rural politics.

Profound challenges facing rural communities have captured national attention. Monoeconomies that once thrived have collapsed, leaving communities, as well as the local governments they depend on, losing population, revenue streams, and optimism. Ghost towns with vacant, crumbling structures scatter the countryside. Many of those left behind have been swept up in the opioid, suicide, and other health crises. While some residents are able to move from "rural" to "urban," mobility is limited for many. These challenges require the best minds in design thinking, technology, and philanthropy to address ways to rebuild legal infrastructure to respond to the needs of rural communities.

Despite increasing attention to rural socioeconomic decline and the "white working class," many populations within rural America remain largely invisible. Native communities, people of color, linguistic and religious minorities, women, undocumented immigrants, and members of the LGBTQ population living in rural areas struggle to secure access to justice and safe livelihoods. Anemic recourse for civil rights violations, a shortage of lawyers, and police misconduct remain unaddressed. In addition to "justice deserts," food deserts, a lack of public transportation, and other infrastructural gaps compound the difficulties of rural life.

Little agreement exists as to the ideal role of law, policy, and legal education in addressing rural disenfranchisement, decline, and alienation. The law itself seems to have a more tenuous hold in rural areas. Rural "lawlessness" sometimes underscores conflicts with broad implications, such as with active bias among different racial and religious groups, many of which have identical disappointing experiences with legal infrastructure. These experiences range from similar lack of access to legal services and support on the one hand to similar disparate treatment by law enforcement on the other. This begs the question: Are "rural" and "law," if not mutually exclusive concepts, in fundamental tension with each other? And what further dissonance is created when we state that law is part of all of us, that it belongs to all of us, as it is a public good, when swaths of society have neither connection to nor reason to trust in the law?

I also challenge common conceptions of rural dualities as they relate to rural identities and politics. For example, I challenge the notion that rurality means unsophisticated, monolithic, and conservative. This is the duality to which I refer. Rurality certainly does not garner attention like international human rights. Tomes are not written on the former. The laws that represent fundamental principles, as opposed to complex regulatory schemes, are not the focus of debate, curriculum, or intensive study for the benefit of rural communities and small " $i$ " innovation in those and similarly situated communities. 
Here is where Rules for a Flat World and the several other works that discuss disrupting law and legal infrastructure get it so wrong and so right all at the same time. Is it really that law and legal infrastructure have made a complex world more complex and unwieldy to the point of inefficiency, or is it that law and legal infrastructure are being built out in a vacuum in which real, societal relationships are discounted as no longer used or useful? Much of institutionalized legal infrastructure is being redeployed to manage what is now a hyper-transactional society. Framed another way, has the evolution of the rule of law let society down or has society and the race for Big "I" innovation let the rule of law down?

The rule of law and legal infrastructure have grappled with intractable human failings over the centuries, yet they have - up to this point — been symbolic of the hope that accompanies the acknowledgement that justice for the many voices and the many identities that define humanity is of paramount importance. One could venture that the greatest aspiration of humankind is not technological innovation and future progress, alone, but how these innovations complement the rule of law to achieve justice for all. I propose that disrupting our conceptions of innovation will help us disrupt the manner in which law has been positioned to reflect an emphasis on promoting the current path toward the hyper-transactional society at the expense of helping society achieve its most noble aspiration - justice for all — through the recognition and embrace of an interdependent humanity built on personal relationships.

Without disrupting society and certain forms of technological innovation, we in American society will continue to experience the heartbreak that results from the demise of communities whose members do not feel better off being governed by the rule of law. Instead of building innovations and technology that complement the rule of law, our innovators and the markets that are manipulated for ostentatious self-interest are geared to profiting a select few in society, while the majority of our vulnerable communities become ever more fearful of and pessimistic about law and legal infrastructure.

There is nothing complex about rural communities and those who are similarly "othered" feeling left out or left behind. Here, I express that continuing on a path that disparages the rule of law as somehow dysfunctional will cast a larger net that will pull more and more members of society into the category of "the left behind." To say there is something wanting in the law and legal infrastructure, without looking at those who have implemented them to be narrowly enjoyed and applied in the name of paving the way for market-regulated technological innovation, is hubris. 